\title{
Shoreline Response to Rapid 20th Century Sea-Level Change along the Iranian Caspian Coast
}

\author{
Author(s): A.A. Kakroodi, S.B. Kroonenberg, A. Goorabi, and M. Yamani \\ Source: Journal of Coastal Research, 30(6):1243-1250. 2013. \\ Published By: Coastal Education and Research Foundation \\ DOI: http://dx.doi.org/10.2112/JCOASTRES-D-12-00173.1 \\ URL: http://www.bioone.org/doi/full/10.2112/JCOASTRES-D-12-00173.1
}

BioOne (www.bioone.org) is a nonprofit, online aggregation of core research in the biological, ecological, and environmental sciences. BioOne provides a sustainable online platform for over 170 journals and books published by nonprofit societies, associations, museums, institutions, and presses.

Your use of this PDF, the BioOne Web site, and all posted and associated content indicates your acceptance of BioOne's Terms of Use, available at www.bioone.org/page/terms_of_use.

Usage of BioOne content is strictly limited to personal, educational, and non-commercial use. Commercial inquiries or rights and permissions requests should be directed to the individual publisher as copyright holder. 


\title{
Shoreline Response to Rapid 20th Century Sea-Level Change along the Iranian Caspian Coast
}

\author{
A.A. Kakroodi ${ }^{\dagger *}$, S.B. Kroonenberg ${ }^{\dagger}$, A. Goorabi ${ }^{\ddagger}$, and M. Yamani ${ }^{\ddagger}$ \\ ${ }^{\dagger}$ Department of Geotechnology \\ Delft University of Technology \\ Delft 2628 CN, The Netherlands \\ $\ddagger$ Department of Physical Geography \\ University of Tehran \\ Tehran, Iran
}

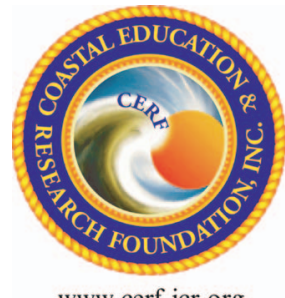

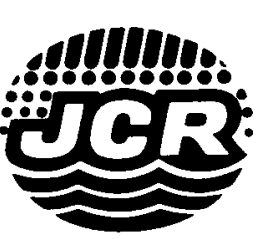

www.JCRonline.org

\begin{abstract}
Kakroodi, A.A.; Kroonenberg, S.B.; Goorabi, A., and Yamani, M., 2014. Shoreline response to rapid 20th century sea-level change along the Iranian Caspian Coast. Journal of Coastal Research, 30(6), 1243-1250. Coconut Creek (Florida), ISSN 0749-0208.

The Caspian Sea, the largest lake in the world, is characterized by rapid sea-level changes. This provides a real physical model of coastal response to rapid sea-level change in a period of just a few years, which might take a millennium along oceanic coasts. Between 1929 and 1995, the Caspian sea level experienced the last cycle, with a range of $\pm 3 \mathrm{~m}$. This caused disastrous effects along the coast and destroyed many buildings, roads, farms, and other human property. During the preceding 48 years of sea-level fall, a large area of the sea bottom emerged, which was then used for the development of residential zones. That area had to be abandoned when sea level rose by almost $3 \mathrm{~m}$ in a period of 18 years. With the use of LANDSAT data, we calculated total shoreline shifts in 22 littoral cells, each cell containing three transects over a 3-km distance. Both landward and seaward shifts occur during rapid sea-level rise between 1977 and 2001.
\end{abstract}

ADDITIONAL INDEX WORDS: Rapid sea-level change, LANDSAT data, seaward and landward shift, Caspian Sea.

\section{INTRODUCTION}

The coastal zone is defined as an interactive environment between two systems, marine and land, interacting (eroding and accreting) in response to external factors, both natural and anthropogenic in origin, and acting on a whole range of time scales (French, 2001). Accelerated sea-level rise since the 19th century is of worldwide concern. Recent data obtained from satellite altimetry since 1992 indicate a general sea-level rise in global mean sea level (GMSL) of around $3.1 \pm 0.4 \mathrm{~mm} / \mathrm{y}$. It is not yet clear how the oceanic coast responds to rapid sea-level changes, and most models focus on different variables, such as temperature, without considering the coastal reaction to possible sea-level rise.

The Caspian Sea (CS) is a closed basin, unconnected to the world's oceans, with an independent sea-level regime and a sea level at about $-27 \mathrm{~m}$ below oceanic level (BOL). Although the Caspian Sea is a lake, and its water level can be considered lake-level changes, it has several aspects in common with the oceans, including its large size, measuring $1200 \mathrm{~km}$ in the N-S direction between $48^{\circ}$ and $36^{\circ} \mathrm{N}$ and more than $326 \mathrm{~km}$ between $48^{\circ}$ and $54^{\circ} \mathrm{E}$; the large volume of water, at around $78,000 \mathrm{~km}^{3}$; the great depth of water, at more than $1000 \mathrm{~m}$; the large catchment area of about 3.5 million $\mathrm{km}^{2}$; and the occurrence of severe storm surges, with heights of $10 \mathrm{~m}$.

The CS has experienced much more rapid sea level changes than the oceans: even in the 20th century, sea level has fluctuated about $3 \mathrm{~m}$, with a maximum rate of sea-level rise in

DOI: 10.2112 / JCOASTRES-D-12-00173.1 received 4 September 2012; accepted in revision 20 November 2012; corrected proofs received 12 January 2013; published pre-print online 5 June 2013.

*Present address: Department of Remote Sensing, University of Tehran, Tehran, Iran; kakroodi_a@yahoo.com

(c) Coastal Education \& Research Foundation 2014 the $1980 \mathrm{~s}$ of up to $34 \mathrm{~cm} / \mathrm{y}$, a hundred times faster than eustatic sea-level rise in the oceans.

The existence of an extensive data base on shoreline changes, as well as tide gauge data from the middle of the 19th century, makes the CS an excellent "natural laboratory" for the study of the response of oceanic coasts to future rapid water-level changes of $1 \mathrm{~m}$ or more (Kaplin and Selivanov, 1995).

On the basis of the tide gauge record, CS sea level was relatively stable between 1850 and 1929 and dropped around 3 $\mathrm{m}$ between 1929 and 1977 in a period of 48 years, from 25.5 to 29.04 BOL. It rose again suddenly between 1977 and 1995 (Figure 1). Within the Holocene, CS sea level experienced many cycles, and the latest two major highstands occurred at ca. 2600 calibrated years BP and during the Little Ice Age (Kakroodi et al., 2012; Kroonenberg et al., 2007).

Generally, a rapid fall in sea level results in seaward progradation of the coastal zone, enticing people to use the emerging sea bottom for residential and industrial development. Rapid sea-level rise results in passive drowning on gentle-gradient coasts and backstepping, accompanied by erosion on steeper coasts (Kaplin and Selivanov, 1995; Storms and Kroonenberg, 2007). The morphology of the eastern Iranian Caspian coast changed completely during the last sea-level cycle between 1929 and 1995 (Kakroodi et al., 2012). The sea-level cycles in this century probably reflect secular variations in precipitation in the Volga drainage basin, which themselves are related to systematic deviations in jet systemrelated circulation patterns (Arpe and Leroy, 2007; Rodionov, 1994). Recent satellite altimetry data such as TOPEX, JASON, and Ocean Surface Topography Mission (OSTM) show that other lakes near the CS basin, such as Lake Urmia, Lake Baikal, and Lake Aral, also experienced a highstand in 1995, a minor sea-level rise in 2005, and a sea-level fall from 2011 


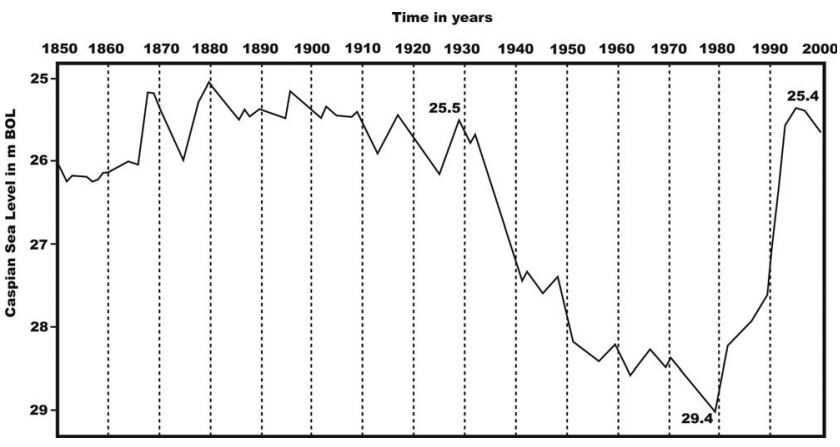

Figure 1. Sea-level curve since 1850. Source: National Iranian Oil Company, compiled by A. Jafari.

onward. This implies that lake levels are influenced by regional climate (Figure 2).

In the present work, the southern Caspian shoreline has been investigated by using LANDSAT data and field observations. We calculated total shoreline shift along the Iranian Caspian coast (Figure 3) during the last phase of sea-level rise between 1977 and 2001.

\section{STUDY AREA}

The study area (Figure 3) is one of the most populated area along the Caspian coast, with a population density of more than 270 persons $/ \mathrm{km}^{2}$. Statistics show that 1.6 million people live within $10 \mathrm{~km}$ of the shoreline, and 3.7 million people live within $50 \mathrm{~km}$ of the shoreline (Pak and Farajzadeh, 2007). Whereas the western and middle parts of the southern Caspian coast are well developed, the eastern and northeastern coasts are less developed. The Iranian Caspian coast has a subtropical climate and a rainfall pattern that shows a strong gradient from 1900 $\mathrm{mm}$ in Anzali in the western part to around $196 \mathrm{~mm}$ in the southeastern corner of the CS (Kakroodi et al., 2012; Pak and Farajzadeh, 2007).

The southern Caspian coast is about $750 \mathrm{~km}$ long. Its beach contains mostly sand to sandy gravel and, in some parts, pebbles and cobbles, depending on the onshore and offshore slope.

Whereas the southwestern and southern Caspian shelves in Iran have steep offshore slopes and correspondingly steep coasts, the offshore gradient in the southeastern Caspian is gentle, which correlates well with the gentle gradient onshore. About 40 million tons of sediment is transported to the coast by 61 rivers, which almost all originate on the northern flank of the Alborz Mountains. Only the Sefid Rud River in the west and the Gorgan Rud River in the east begin their courses from the Zagros and Kopet Dagh Mountains, respectively (Lahijani, Tavakoli, and Amini, 2008).

Because tides are negligible in the $\mathrm{CS}$, waves, marine currents, coastal nearshore morphology, and rapid sea-level change are the most important factors that control coastal morphology (Kakroodi et al., 2012).
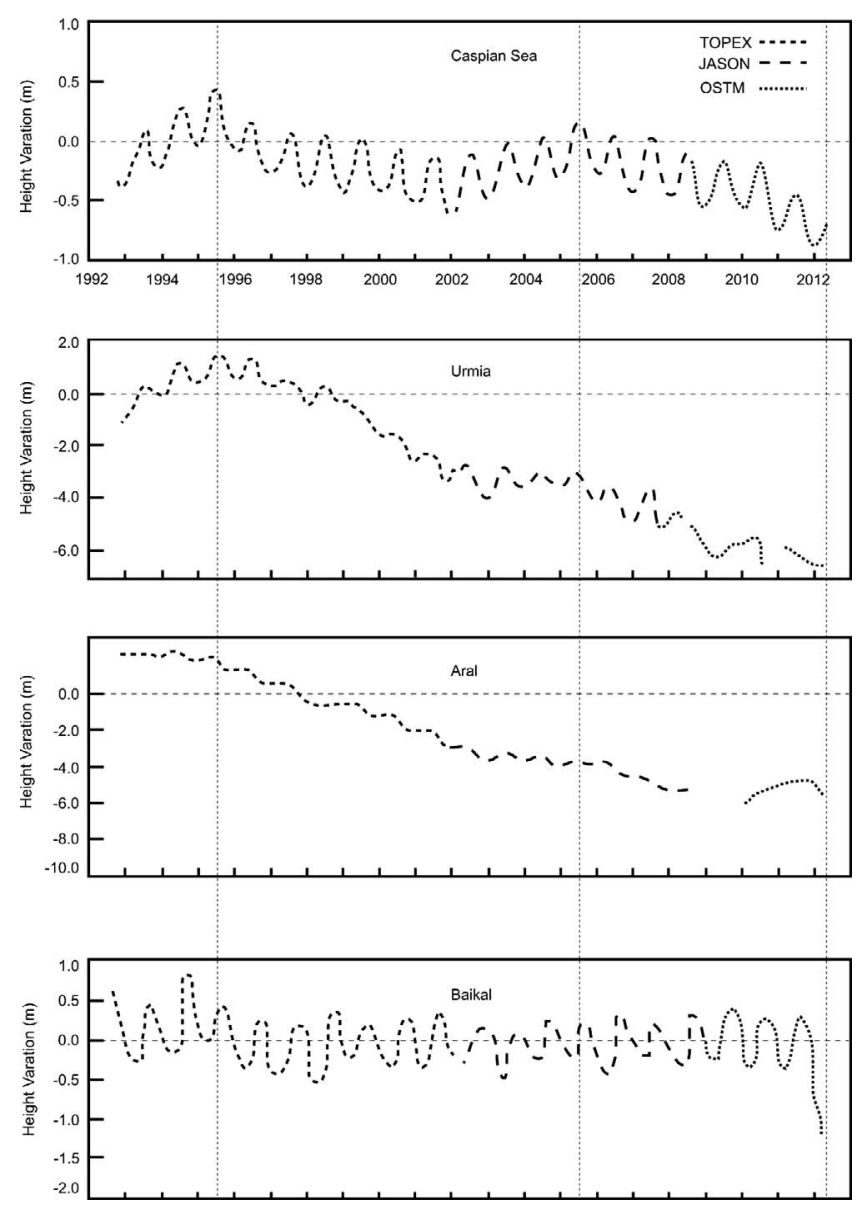

Figure 2. Height variation of Caspian Sea sea level and surrounding lakes based on TOPEX, JASON, and OSTM data. All have a highstand in 1995, a minor sea-level rise in 2005, and a minor fall in 2012 like the CS.

\section{MATERIALS AND METHODS}

This study used LANDSAT satellite data from the whole southern Iranian coast (Table 1) in conjunction with field observations to detect the shoreline shifts during rapid sealevel rise of the CS between 1975 and 2001. No data are available during sea-level fall between 1929 and 1977 except an old map in the eastern part and some aerial photographs in the Sefid Rud delta area. LANDSAT data are available from the Global Land Cover Facility website (GLCF, 2012).

Topographic maps at 1:25,000 scale were used for geocoding satellite data. The southern CS coast has been subdivided into 22 littoral cells (LC), and each cell has three transects (except LC19 with two transects) over a $3-\mathrm{km}$ distance. Therefore, nearly full coverage of the study area was selected (Figure 3). Shoreline shifts were extracted in ENVIE 4.5 from band 4 of LANDSAT data, and the edge enhancement technique (High Pass Filter with an Image Add Back 80\%) was applied (Maiti and Bhattacharya, 2008). In total, five multispectral scanner (MSS) scenes, five thematic mapper (TM) scenes, and five enhanced TM (ETM) scenes of near infrared bands have been used (Table 1). The near infrared band of ETM imagery was 


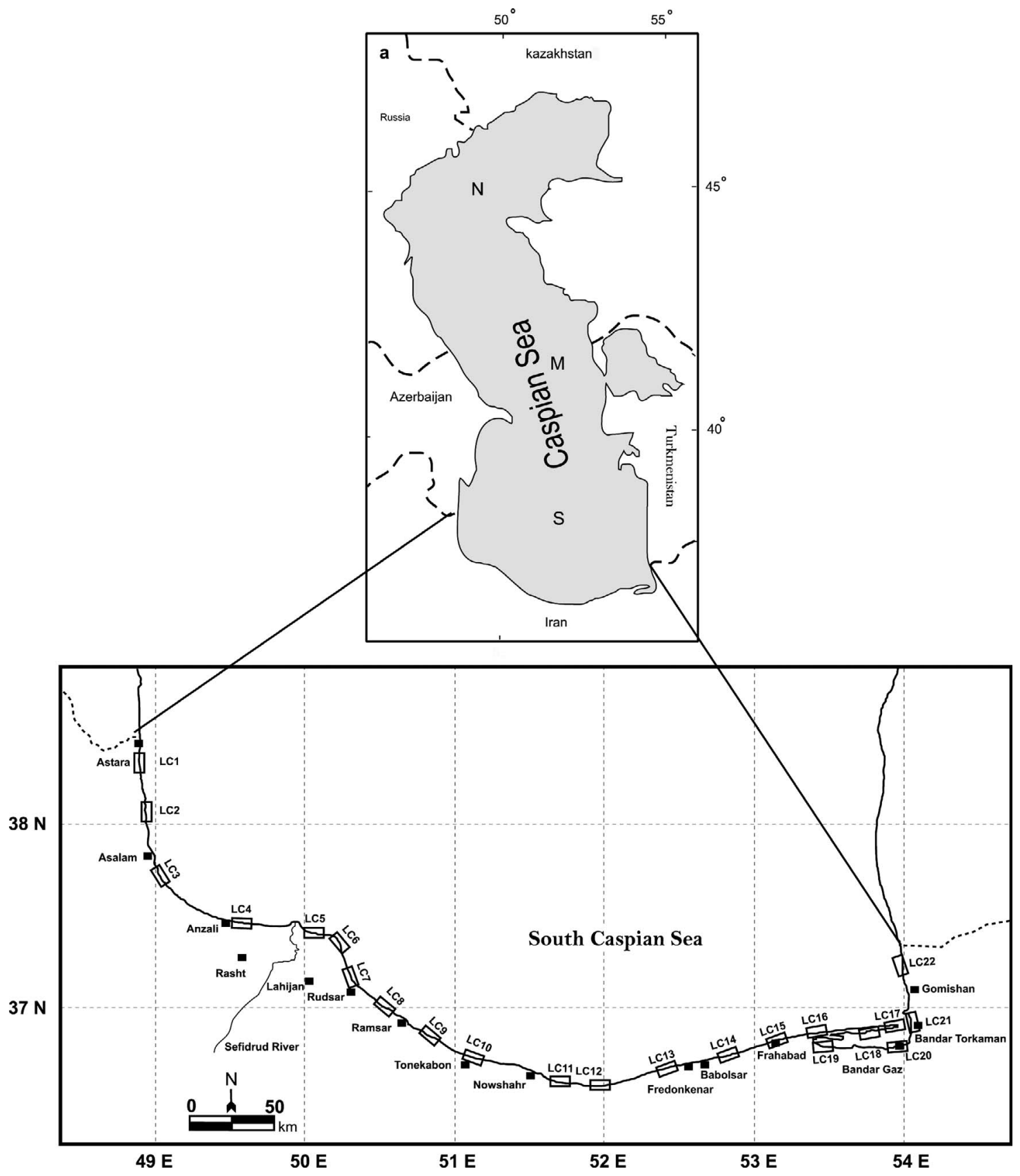

Figure 3. The CS and location of the study area (a) and 22 littoral cells along the southern Caspian coast (b).

first selected and corrected by using the 1:25,000 topographic map and resampled to a 60-m pixel size. Thus, all LANDSAT data were georeferenced through image-to-image registration with the same pixel size. Root mean square error ranged between 0.05 and 0.1 pixel, showing 3-6 m error in georeferencing. Finally, the shoreline was digitized manually, and three vector layers were made, indicating total shoreline shifts between 1975 and 2001. The final outputs show the total estimation for shoreline change during rapid CS sea-level rise (Figure 4).
No bathymetry map was available, but the geologic map associated with bathymetry gave a general offshore slope that can be measured with the equation (slope degree) = arctan(rise/ run).

\section{RESULTS}

\section{General Coastal Aspects}

Figure 5 illustrates the different morphology of the southern Iranian coasts in 2001 between the shoreline around $27 \mathrm{~m} \mathrm{BOL}$ 
Table 1. LANDSAT data ID used in the present study.

\begin{tabular}{|c|c|c|c|c|}
\hline Sensor & Record Time & Littoral Cell & $\begin{array}{c}\text { Spatial } \\
\text { Resolution }\end{array}$ & $\begin{array}{l}\text { Sea Level } \\
\text { (BOL) }\end{array}$ \\
\hline MSS & 10 April 1975 & 1,2 & 79 & ca. 28.7 \\
\hline MSS & 27 July 1975 & 3,4 & 79 & ca. 28.7 \\
\hline MSS & 10 July 1978 & $5-11$ & 79 & ca. 28.9 \\
\hline MSS & 13 July 1977 & $12-14$ & 79 & ca. 29.04 \\
\hline MSS & 7 April 1975 & $15-22$ & 79 & ca. 28.7 \\
\hline TM & 10 June 1987 & 1,2 & 30 & ca. 27.8 \\
\hline $\mathrm{TM}$ & 2 July 1989 & 3,4 & 30 & ca. 27.6 \\
\hline TM & 8 May 1989 & $5-11$ & 30 & ca. 27.6 \\
\hline TM & 19 September 1988 & $12-14$ & 30 & ca. 27.7 \\
\hline TM & 16 July 1987 & $15-22$ & 30 & ca. 27.8 \\
\hline ETM & 5 June 2000 & 1,2 & 30 & ca. 25.7 \\
\hline ETM & 30 June 2000 & 3,4 & 30 & ca. 25.7 \\
\hline ETM & 25 July 2000 & $5-11$ & 30 & ca. 25.7 \\
\hline ETM & 18 July 2000 & $12-14$ & 30 & ca. 25.7 \\
\hline ETM & 30 July 2001 & $15-22$ & 30 & ca. 25.8 \\
\hline
\end{tabular}

and the 0-m contour line. Typical morphological features include spit lagoon, barrier lagoon, and deltaic coasts. Anzali lagoon and the Sefid Rud delta (Figure 5, LC4 and LC5) are predominant features in the western part of the Iranian coast. The Sefid Rud delta provides $70 \%$ of total sediment supply to the CS along the Iranian coast (Lahijani, Tavakoli, and Amini, 2008). During sea-level fall, the delta is largely a riverdominated delta and during sea-level rise, a wave-dominated delta. The Miankaleh spit is around $60 \mathrm{~km}(\mathrm{LC} 16,17)$ and is separated from the land by Gorgan Bay (LC18, 19, 20). No data from Miankaleh are available for 1995, but the satellite data from 2001 show that the spit was breached and disintegrated into several islands, and the spit lost half of its width (Kakroodi et al., 2012).

Another lagoon, Hassan Gholi Bay, was a dominant feature in the study area until 1890, but it fell dry during the major drop in sea level (Kakroodi et al., 2012). During rapid sea-level rise after 1977, another lagoon formed at a more seaward position than previously (LC22).

Between 1987 and 1995, the CS reached the maximum level, and its coast experienced much erosion and landward shift.

No data are available during the rapid sea-level fall between 1929 and 1977. The only available data are an old map from 1890 covering the eastern part and aerial photographs from 1955 covering the Sefid Rud delta area. According to Kaplin and Selivanov (1995) and Ignatov et al. (1993), the rate of regression during rapid sea-level fall was 60-100 and 150-200 $\mathrm{m} / \mathrm{y}$ in the northeastern and northwestern CS, respectively, and $700-800 \mathrm{~m} / \mathrm{y}$ in Komsomoletz Bay in the north, mainly in lagoonal environments. During seaward shift, roads and various industrial and residential structures were built on the former sea floor (Kaplin and Selivanov, 1995).

On the basis of MSS data from 1977 and an old map from 1890 , three islands of the Miankaleh spit were connected by longshore currents during sea-level fall, and the spit extended eastward at a rate of $40-110 \mathrm{~m} / \mathrm{y}$ (LC17). The Gorgan delta prograded around $85 \mathrm{~m} / \mathrm{y}$ and 555-640 m/y east of Gorgan Bay along the Iranian mainland (Kakroodi et al., 2012). Between 1955 and 1977, the level of the CS dropped around $70 \mathrm{~cm}$, and based on aerial photographs from 1955, the Sefid Rud delta prograded around $57 \mathrm{~m} / \mathrm{y}$. The real seaward shift from 1929 is

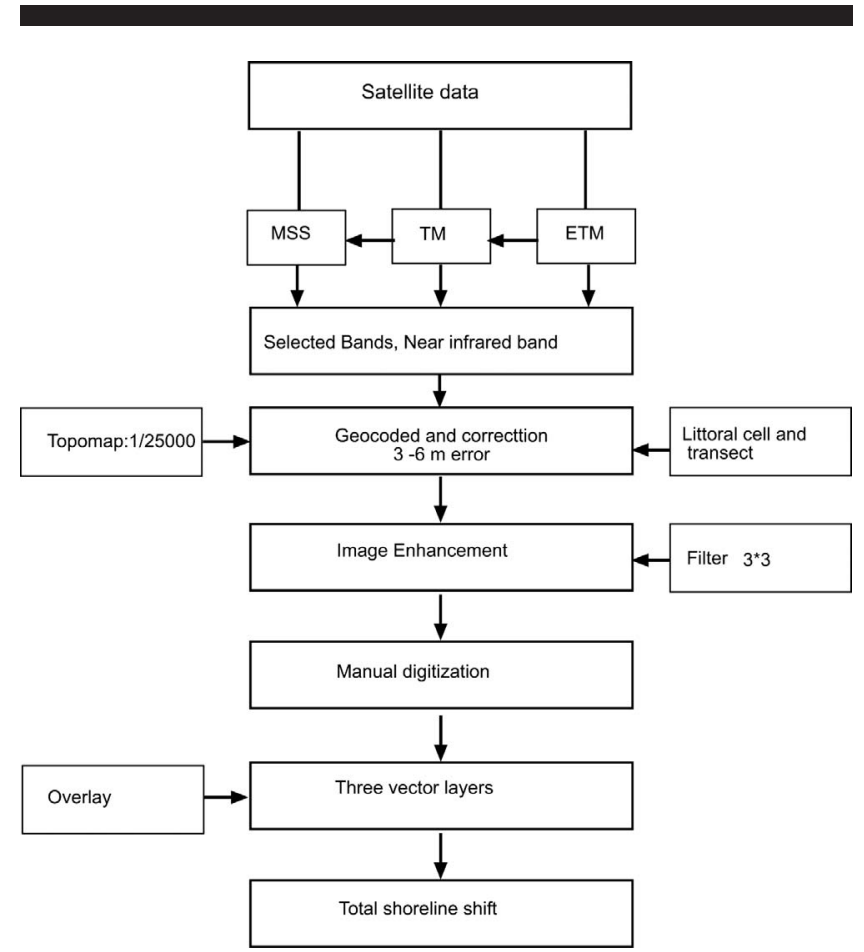

Figure 4. Flowchart of the present work stages.

not clear, but if we suppose the barrier complex belonged to the 1929 shoreline (Figure 6), it ranged around $120 \mathrm{~m} / \mathrm{y}$.

The 1975 LANDSAT MSS data are almost contemporaneous with the 1977 lowstand. TM and ETM data are contemporaneous to CS sea-level rise and the highest record in 1995 (Figure 1). Table 2 presents the total shoreline shifts on the southern Iranian coast during rapid sea-level rise extracted from LANDSAT data. It also contains all littoral cells with at least three transects. Figure 7 indicates shoreline shift within LC22 in the ETM subscene.

The first column refers to MSS and TM images taken between 1975 and 1989, and the second column refers to the TM and ETM images taken in 1987 and 2001 (Table 2). Negative values indicate seaward shift. LC5 is the only cell that indicates a negative value as a sum of three transactions. Other negative values are observed in some transactions, such as LC6, 9, 10, and 16.

From LC1 to LC3, the coast is characterized by elongated and small lagoons, with pebble and cobble beach in LC3. Most sand progradation occurs between LC4 and LC5 where the Sefid Rud and nearby rivers provide sufficient sediments for the beach. Table 3 summarizes general coastal aspects along the southern Iranian Caspian and indicates different coastal types along the southern Caspian coast from LC1 to LC22.

\section{DISCUSSION}

\section{Shoreline Shifts during Rapid Sea-Level Rise between 1977 and 2001}

Unlike sea-level fall, the rapid sea-level rise has been well recorded by LANDSAT data since 1977. Figure 8 presents total 

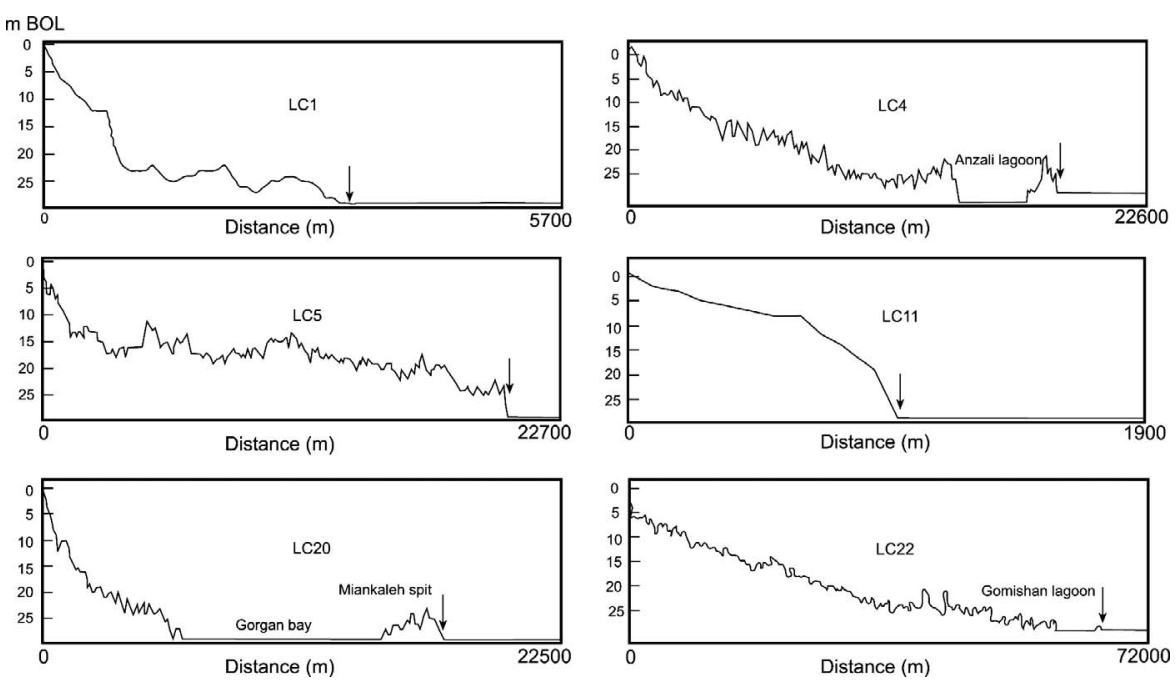

Figure 5. Different coastal types along the southern Caspian coast derived from Shuttle Radar Topography Mission. The arrows indicate the 2001 shoreline. Note the distance between the 2001 shoreline and counterline of 0 m. LC1, steep slope; LC4, gentle slope with barrier lagoon system; LC5, delta; LC11, very steep slope; LC20, gentle slope with spit lagoon; LC22, very low angle coast with barrier lagoon system.

shoreline shifts within LCs during rapid sea-level rise between 1975 and 2001 along the southern Caspian coast.

\section{Seaward Shift during Rapid Sea-Level Rise}

The seaward shift during sea-level rise occurred in the areas with high sediment supply and areas influenced by anthropogenic activities. Seaward shifts during rapid sealevel rise have been observed in LC5 (transect [Tr.] 1, 2), 6 (Tr. 3), 9 (Tr. 3), 10 (Tr. 3), and 16 (Tr. 1). Progradation in the barrier lagoon and delta environments between LC5 and LC6 is mainly due to sediment supply of the Sefid Rud delta and nearby rivers (Figure 9). This is a very important observed phenomenon along the Iranian coast near the biggest river, Sefid Rud, which indicates that delta progradation can

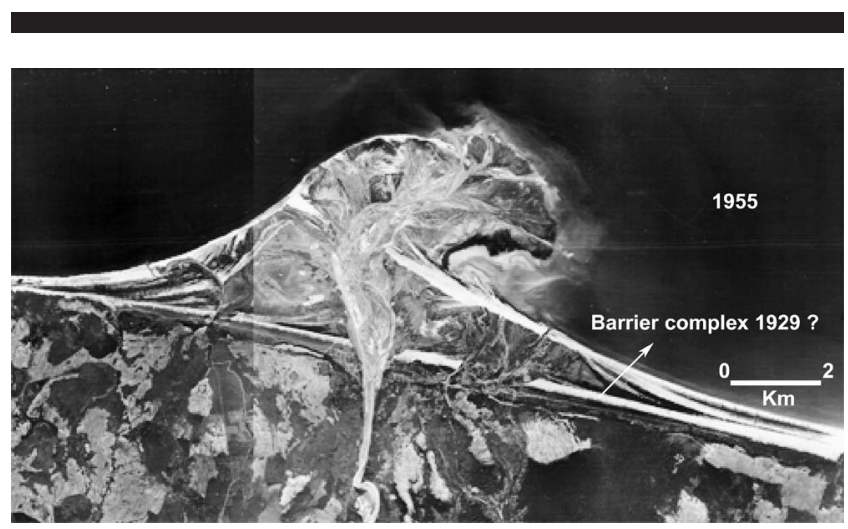

Figure 6. The Sefid Rud delta in 1955 during the rapid sea-level fall. It is a river-dominated delta with some wave influence at the western part of delta. compensate even a $3-\mathrm{m}$ sea-level rise over 18 years. There was totally a different situation on the other major delta at the eastern part of the Iranian on the Gorgan delta, which retrograded at a rate of $140 \mathrm{~m} / \mathrm{y}$ during rapid sea-level rise. (Kakroodi et al., 2012).

The Farahabad and Miankaleh coasts are strongly influenced by human activities, at least over the past 40 years. Whereas main accretion of sand occurred in the direction of lateral sediment transport, particularly on the perpendicular obstruction of coastal zones like ports, extreme erosion acted on the other side (LC16). Therefore, anthropogenic effects resulted in both accretion and erosion simultaneously.

\section{Landward Shift during Rapid Sea-Level Rise}

There is a general increase of landward shift from LC1 to LC23, from the western to the eastern Iranian Caspian coast.

The coast between LC1 and LC3, characterized by small barrier lagoon systems, and the distance between contour line 0 and the present shoreline is short (Figure 5). There is more accommodation space in this part than the eastern part of the Iranian coasts. The mean rate of landward shift in LC1, LC2, and LC3 ranges from 8.5 to $17.7 \mathrm{~m} / \mathrm{y}$. Many trees and some buildings were drowned in these areas (Figure 10).

The mean landward shift in LC4, around $4.6 \mathrm{~m} / \mathrm{y}$, indicates a lower rate than in the previous cells. The only landward shift in LC5 occurs in Tr. 3 around $2.2 \mathrm{~m} / \mathrm{y}$. It seems there is a balance between the rate of landward shift and sediment supply, mainly from the Sefid Rud River and nearby rivers. The landward shift is limited to a few meter per year because of high sediment input.

LC6 (Tr. 1, 2) is located in a coastal bend in the old Sefid Rud delta area. The mean landward shift is high and reached $16 \mathrm{~m} / \mathrm{y}$ by erosion of the unconsolidated sediments deposited by the Sefid Rud River. 
Table 2. Shoreline shifts extracted from LANDSAT data between 1975 and 2001 along the Iranian coast.

\begin{tabular}{|c|c|c|c|c|c|}
\hline \multirow[t]{2}{*}{$\mathrm{LC}$} & \multirow[t]{2}{*}{ Tr. No. } & \multicolumn{2}{|c|}{ Shoreline Shift $(\mathrm{m} / \mathrm{y})$} & \multirow[t]{2}{*}{ Sum } & \multirow[t]{2}{*}{ Mean } \\
\hline & & $1975-1987$ & $1987-2000$ & & \\
\hline \multirow[t]{3}{*}{ LC1 } & 1 & 510 & 60 & 570 & 446 \\
\hline & 2 & 123 & 285 & 408 & \\
\hline & 3 & 270 & 90 & 360 & \\
\hline \multirow[t]{4}{*}{ LC2 } & 1 & 180 & 255 & 435 & 300 \\
\hline & 2 & 150 & 120 & 270 & \\
\hline & 3 & 120 & 75 & 195 & \\
\hline & & 1975-1989 & 1989-2000 & & \\
\hline \multirow[t]{3}{*}{ LC3 } & 1 & 87 & 138 & 225 & 214 \\
\hline & 2 & 63 & 120 & 183 & \\
\hline & 3 & 96 & 138 & 234 & \\
\hline \multirow[t]{4}{*}{ LC4 } & 1 & 128 & 30 & 158 & 115 \\
\hline & 2 & 33 & 91 & 124 & \\
\hline & 3 & -42 & 105 & 63 & \\
\hline & & 1978-1989 & $1989-2000$ & & \\
\hline \multirow[t]{3}{*}{ LC5 } & 1 & -225 & 90 & -135 & -55 \\
\hline & 2 & -45 & -33 & -78 & \\
\hline & 3 & 15 & 33 & 48 & \\
\hline \multirow[t]{3}{*}{ LC6 } & 1 & 87 & 100 & 187 & 181 \\
\hline & 2 & 138 & 349 & 487 & \\
\hline & 3 & -130 & 0 & -130 & \\
\hline \multirow[t]{3}{*}{ LC7 } & 1 & 54 & 47 & 101 & 71 \\
\hline & 2 & 47 & 33 & 80 & \\
\hline & 3 & -15 & 47 & 32 & \\
\hline LC8 & 1 & 75 & 87 & 162 & 133.6 \\
\hline & 2 & 75 & 89 & 164 & \\
\hline & 3 & 75 & 0 & 75 & \\
\hline LC9 & 1 & 31 & 33 & 64 & 35.6 \\
\hline & 2 & 27 & 37 & 64 & \\
\hline & 3 & -42 & 21 & -21 & \\
\hline LC10 & 1 & 70 & 61 & 131 & \\
\hline & 2 & 48 & 31 & 79 & \\
\hline & 3 & -17 & -6 & -23 & \\
\hline & & $1977-1988$ & $1988-2000$ & & \\
\hline LC11 & 1 & - & 38 & 38 & 43.3 \\
\hline & 2 & - & 52 & 52 & \\
\hline & 3 & - & 40 & 40 & \\
\hline LC12 & 1 & 67 & 30 & 97 & 133.6 \\
\hline & 2 & 90 & 75 & 165 & \\
\hline & 3 & 45 & 94 & 139 & \\
\hline LC13 & 1 & 124 & 134 & 258 & 265.3 \\
\hline & 2 & 138 & 91 & 229 & \\
\hline & 3 & 200 & 109 & 309 & \\
\hline LC14 & 1 & 171 & 84 & 255 & 239.3 \\
\hline & 2 & 76 & 135 & 211 & \\
\hline & 3 & 190 & 62 & 252 & \\
\hline & & $1975-1987$ & $1987-2001$ & & \\
\hline LC15 & 1 & 45 & 60 & 105 & 74 \\
\hline & 2 & -33 & 90 & 57 & \\
\hline & 3 & -75 & 135 & 60 & \\
\hline LC16 & 1 & -61 & -225 & -286 & 60 \\
\hline & 2 & -45 & 270 & 225 & \\
\hline & 3 & 85 & 156 & 241 & \\
\hline LC17 & 1 & 1080 & 150 & 1230 & 1870 \\
\hline & 2 & 765 & 1260 & 2025 & \\
\hline & 3 & 2040 & 315 & 2355 & \\
\hline LC18 & 1 & 90 & 50 & 140 & 207.3 \\
\hline & 2 & 75 & 152 & 227 & \\
\hline & 3 & 75 & 180 & 255 & \\
\hline LC19 & 1 & 19320 & 2820 & 22140 & 22710 \\
\hline & 2 & 20690 & 2590 & 23280 & \\
\hline LC20 & 1 & 210 & 105 & 315 & 435 \\
\hline & 2 & 330 & 360 & 690 & \\
\hline & 3 & 105 & 195 & 300 & \\
\hline LC21 & 1 & 195 & 750 & 945 & 815 \\
\hline & 2 & 390 & 285 & 675 & \\
\hline & 3 & 585 & 240 & 825 & \\
\hline
\end{tabular}

Table 2. Continued.

\begin{tabular}{lclrrr}
\hline \hline LC & Tr. No. & \multicolumn{2}{l}{ Shoreline Shift $(\mathrm{m} / \mathrm{y})$} & Sum & Mean \\
\hline LC22 & 1 & 3400 & 644 & 4044 & 5140 \\
& 2 & 3700 & 1760 & 5460 & \\
& 3 & 4096 & 1820 & 5916 & \\
\hline
\end{tabular}

The landward shift is $3.3 \mathrm{~m} / \mathrm{y}$ in LC7, showing a lower rate than in LC6. Its coast is characterized by sand progradation and high sediment supply, as occurred in LC5, but at a lower value.

Erosion along the coast during sea-level rise is particularly visible between LC8 and LC12 because of the steep slope. The distance of the two contour lines in LC11 is short, and LC10 shows the maximum slope along the whole southern Caspian coast (Figure 5). Many buildings and trees were drowned in these areas, particularly in LC8 (Figure 11), although the main rate of landward shift is low. The mean landward shifts between LC8 and LC12 range from 1.7 to $6.3 \mathrm{~m} / \mathrm{y}$.

From west to east, the amount of cobbles, pebbles, and coarse sand decreases, whereas sand increases eastward. From LC12

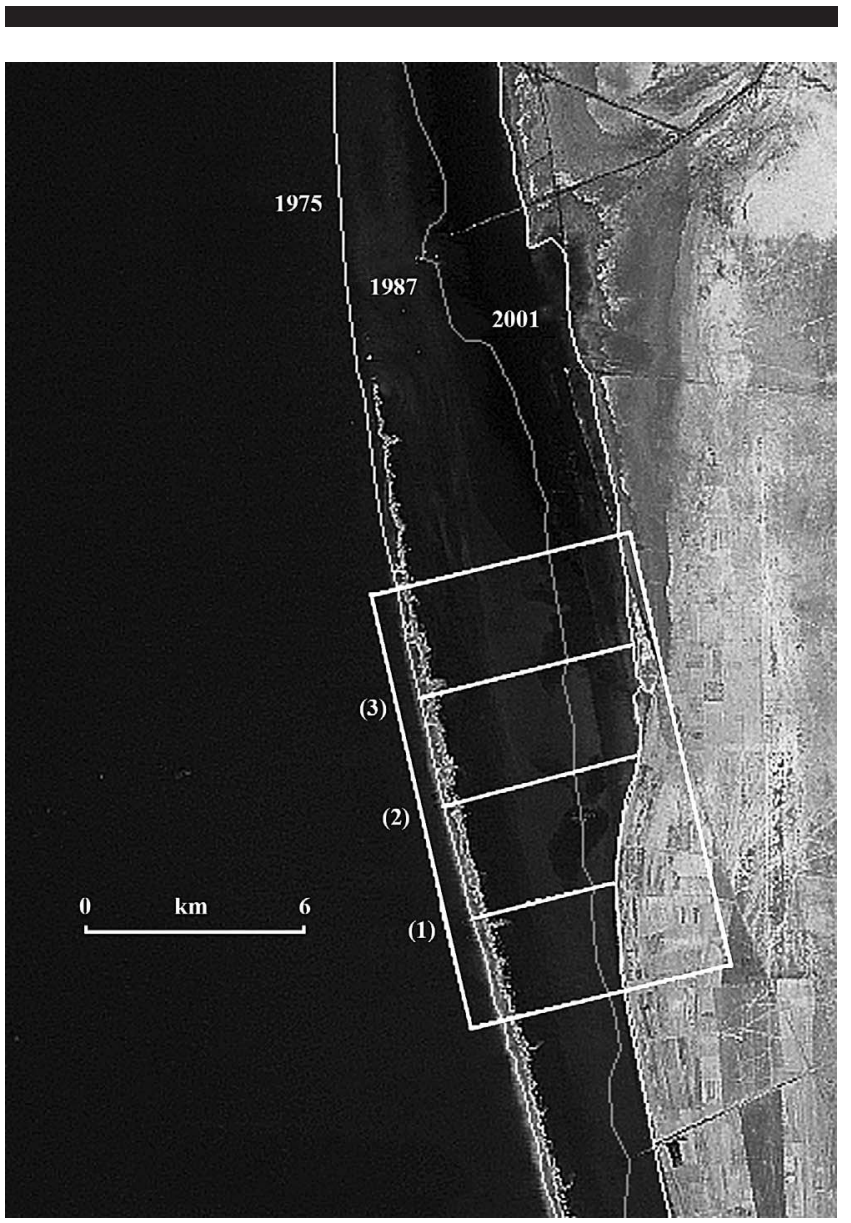

Figure 7. Shoreline shift within LC22. 
Table 3. Field observation of coastal aspects of littoral cells in 2008. Slope values within littoral cell are between present shoreline and 7 km offshore for all transects (in degrees).

\begin{tabular}{|c|c|}
\hline $\mathrm{LC}$ & Coastal Aspect \\
\hline LC1, 2 & Beach sand, small berm, backshore depression, washover and drowned trees \\
\hline LC3 & Beach pebble, cobble, drowned building and tree \\
\hline LC4 & Beach sand, strong sand progradation, low transgression \\
\hline LC5 & Beach sand, strong sand progradation, delta influence, seaward shift during sea-level rise \\
\hline LC6 & Old delta area, strong landward shift, seaward shift, drowned building and protective wall, shoreline bend \\
\hline LC7 & Beach sand, strong sand progradation, seaward shift during sea-level rise \\
\hline LC8 & Narrow beach sand, drowned building and tree, deep slope, protective wall \\
\hline LC9 & Pebble and cobble coast, erosional coast, $0.22^{\circ}$ \\
\hline $\mathrm{LC} 10,11,12$ & Pebble and cobble coast, deep slope, erosional coast, protective wall, $0.32^{\circ}$ \\
\hline $\mathrm{LC} 13,14,15$ & Beach sand, strong sand progradation, aeolian deposit \\
\hline LC16, 17 & Beach sand, spit lagoon, strong accretion and erosion, anthropogenic effect, $0.11^{\circ}$ \\
\hline LC17 & Beach sand, spit lagoon, extreme erosion, end of spit and trapping sediments \\
\hline LC18 & Beach sand, spit lagoon, coarse sand, near the narrow channel connected to the sea \\
\hline LC19 & Lagoon, muddy deposits, maximum transgression, drowned road and farms, gentle slope \\
\hline LC20 & Lagoon, muddy deposits, anthropogenic effect \\
\hline LC21 & Gentle slope, muddy deposits, strong landward shift, drowned residential zone and protective wall \\
\hline LC22 & $\begin{array}{l}\text { Lagoon, passive wave circumstance, muddy deposits, strong landward shift, drowned farms and roads, gentle slope } \\
\text { both offshore and onshore, } 0.05^{\circ}\end{array}$ \\
\hline
\end{tabular}

eastward, the coastal plain becomes wider, and the coast receives sand via predominantly eastward longshore transportation, leading locally to spit or barrier lagoon environments (Kakroodi et al., 2012). These areas, from LC13 to LC15, show stronger landward shifts than the previous cells, up to $12 \mathrm{~m} / \mathrm{y}$ in LC13.

A long spit starts at LC16 to the east and ends in Tr. 4 at LC17. The amount of mean landward shift increases eastward, reaching $71.2 \mathrm{~m} / \mathrm{y}$ in LC17. LC18, 19, and 20 are located at the mainland side of Gorgan Bay and experienced extreme landward shift due to growth of the lagoon. Whereas LC18, just opposite the seaward spit, shows lower landward shift $(7.9 \mathrm{~m} / \mathrm{y})$ than LC17, LC19 shows extreme landward shifts over all LCs. A large area emerged during sea-level fall from 1929 to 1977, and many roads and farms were constructed on the newly emerged sea bottom. During sea-level rise, most of them drowned. The mean rate

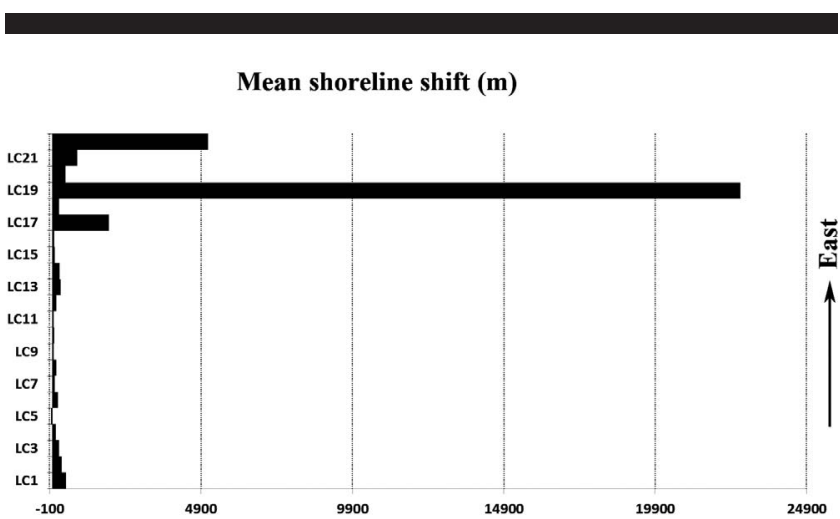

Figure 8. Mean shoreline shift between 1975 and 2001 for each cell between LC1 and LC23. LC19 has only two transects, others have three transects. See Figure 1 for locations. Both landward and seaward shoreline shifts occurred during rapid sea-level rise. of landward shift at the eastern sides of Gorgan Bay was around $865 \mathrm{~m} / \mathrm{y}$ in LC19 (Tr. 1). LC20 indicates a lower average value than LC19 and reached $16.6 \mathrm{~m} / \mathrm{y}$. LC21 is located in the Gorgan delta area and exhibits a different behaviour than the Sefid Rud delta. Whereas the Sefid Rud delta also experienced seaward shift during rapid sea-level rise, the Gorgan delta area experienced high landward shifts, and one residential zone (Chopaghli) near the delta totally drowned. The amount of landward shift reached 31 $\mathrm{m} / \mathrm{y}$ in this part. The west-facing coast in the southern corner of the CS is also a low-angle coast that developed lagoon barrier systems during rapid sea-level rise. Here, a shallow S-N-stretching lagoon has been formed, and the mean landward shift was $195.8 \mathrm{~m} / \mathrm{y}$.

\section{CONCLUSIONS}

Multitemporal LANDSAT images have shown to be a powerful tool in the study of recent shoreline changes as result of the last sea-level cycle of the CS between 1929 and 1995.

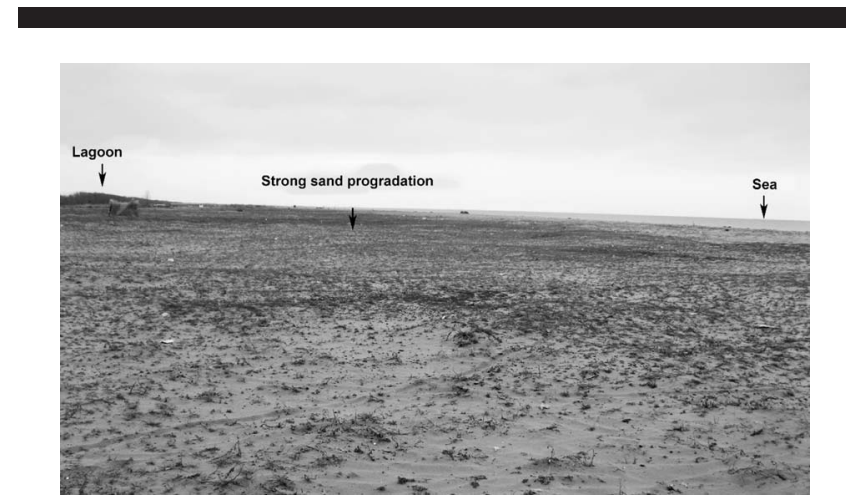

Figure 9. Coastal progradation near the biggest river (Sefid Rud) along the Iranian coast in LC5. 


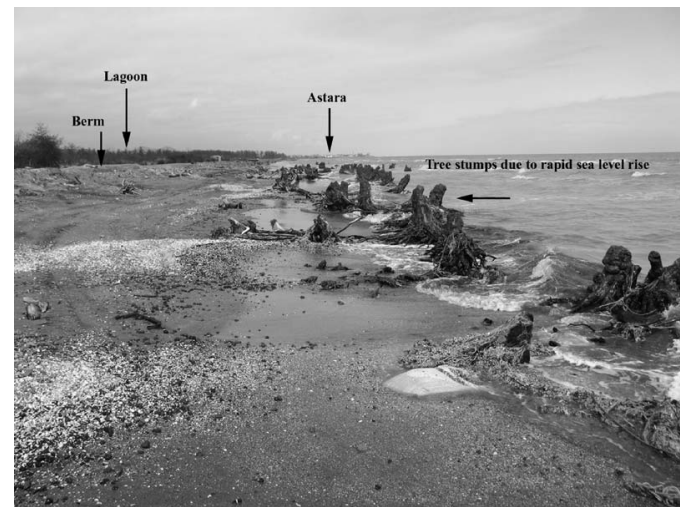

Figure 10. Rapid landward shift in LC1, as shown by abundant tree stumps within the sea.

Although large parts of, especially, the low-angle coasts emerged during sea-level fall between 1929 and 1977, rapid sea-level rise between 1977 and 1995 led to both landward and seaward shoreline shifts. Maximum landward shifts of up to more than $1.7 \mathrm{~km} / \mathrm{y}$ during sea-level rise have been observed in low-angle coasts, mostly in lagoon barrier environments. Minor landward and seaward shoreline shifts, in spite of $3 \mathrm{~m}$ of sealevel rise, occur especially in delta areas where there is enough sediment supply to compensate the increasing accommodation space. Our data show that the coastline also is influenced everywhere, apart from the onshore and offshore slope, by other local factors, such as sediment supply, wave energy, lateral sedimentation transport, and other coastal morphology factors. By including previous results (Kaplin and Selivanov, 1995), the ideal two-dimensional coastal profiles, as postulated by the Bruun rule and other hypotheses, have to develop into three-dimensional models (Geleynse et al., 2011; Storms et al., 2002).

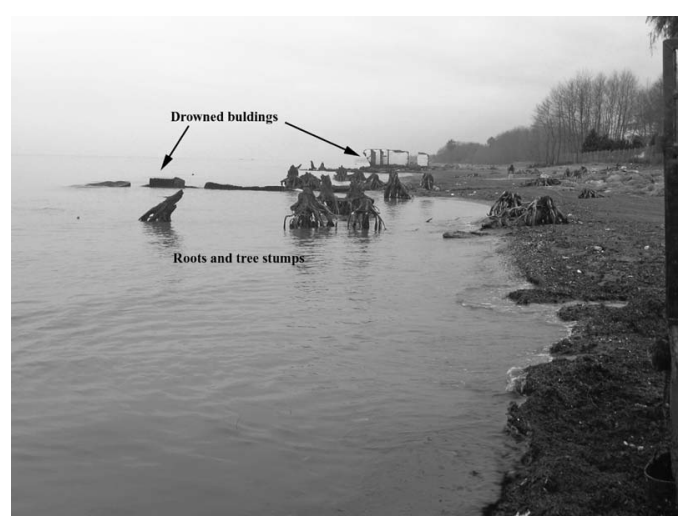

Figure 11. Drowned buildings and roots in LC8.

\section{LITERATURE CITED}

Arpe, K. and Leroy, S.A.G., 2007. The Caspian Sea-level forced by the atmospheric circulation, 964 as observed and modelled. Quaternary International, 173(174), 144-152.

French, P.W., 2001. Coastal Defences: Processes, Problems and Solutions. London: Routledge, 366p.

Geleynse, N.; Storms, J.E.A.; Walstra, D.J.R.; Jagers, H.R.A., and Stive, M.J.F., 2011. Controls on river delta formation; insights from numerical modelling. Earth and Planetary Science Letters, 302(12), 217-226.

GLCF (Global Land Cover Facility), 2012. http://www.landcover.org/ data.

Ignatov, E.I.; Kaplin, P.A.; Lukyanova, S.A., and Solovyova, G.D., 1993. Influence of the recent transgression of the Caspian Sea on its coastal dynamics. Journal of Coastal Research, 9(1), 104111.

Kakroodi, A.A.; Kroonenberg, S.B.; Hoogendoorn, R.M.; Mohammadkhani, H.; Yamani, M.; Ghassemi, M.R., and Lahijani, H.A.K., 2012. Rapid Holocene sea-level changes along the Iranian Caspian coast. Quaternary International, 263, 93-103.

Kaplin, P.A. and Selivanov, A.O., 1995. Recent coastal evolution of the Caspian Sea as a natural model for coastal response to the possible acceleration of global sea-level rise. Marine Geology, 124, 171-178.

Kroonenberg, S.B.; Abdurakhmanov, G.M.; Badyukova, E.N.; van der Borg, K.; Kalashnikov, A.; Kasimov, N.S.; Rychagov, G.I.; Svitoch, A.A.; Vonhof, H.B., and Wesselingh, F.P., 2007. Solar-forced 2600 $\mathrm{BP}$ and Little Ice Age highstands of the Caspian Sea. Quaternary International, 173-174, 137-143.

Lahijani, H.; Tavakoli, V., and Amini, A., 2008. River mouth configuration in south Caspian coast, Iran. Environmental Sciences, 5(2), 65-86.

Maiti, S. and Bhattacharya, A.K., 2008. Shoreline change analysis and its application to prediction: a remote sensing and statistics based approach. Marine Geology, 257, 11-23.

Pak, A. and Farajzadeh, M., 2007. Iran's Integrated Coastal Management plan: Persian Gulf, Oman Sea, and southern Caspian Sea coastlines. Ocean \& Coastal Management, 50, 754-773.

Rodionov, S.N., 1994. Global and Regional Climate Interaction: The Caspian Sea Experience. Water Science and Technology Library, Volume 11. Dordrecht, The Netherlands: Kluwer Academic, $241 p$.

Storms, J.E.A. and Kroonenberg, S.B., 2007. The Impact of Rapid SeaLevel Changes on Recent Azerbaijan Beach Ridges. Journal of Coastal Research, 23(2), 521-527.

Storms, J.E.A.; Weltje, G.J.; van Dijke, J.J.; Geel., C.R., and Kroonenberg, S.B., 2002. Process-response modeling of wavedominated coastal systems: simulating evolution and stratigraphy on geological timescales. Journal of Sedimentary Research, 72 , 226-239. 